\title{
Production of Petroleum - like Fractions from Waste Cooking Oil
}

\author{
Salwa, A. E Khatib $^{1}{ }^{*}$, Samia, A. Hanafi ${ }^{1}$, M.M.H. Arief ${ }^{2}$ \\ and Eslam, F. Al-Amrousi ${ }^{1 *}$ \\ ${ }^{1}$ Petroleum Refining Department, Egyptian Petroleum \\ Research Institute, Nasr City, Cairo, ${ }^{2}$ Faculty of Science, \\ Benha University, Egypt.
}

\begin{abstract}
TYDROCRACKING technique was applied here for producing petroleum- like fractions from waste frying oil. The experiments were performed in a fixed bed flow reactor system, under high pressure using zeolite catalyst. The operating conditions were optimized and found to be $400^{\circ} \mathrm{C}, 2.5 \mathrm{MPahy}$ drogen pressure and $5 \mathrm{~h}^{-1}$ LHSV.

The obtained biofuel was fractionated to gasoline, kerosene and gas oil- like fractions. All the required analyses were accomplished and the data were evaluated. The results indicate that the properties of the attained products are completely compatible with those of the corresponding distillates ensued from petroleum source.
\end{abstract}

Keywords: Biofuel, Hydrocracking, Waste cooking oil.

With the progressive exhaustion of petroleum oil reserves, and in serious consideration of environmental issues, a worldwide trend is concentrated on searching for alternative and renewable energy sources [1-3]

Recently, biofuel derived from vegetable oils is receiving a great attention as the most suitable and logical alternative of fossil fuel [4-6]. Considering the problem arising from the intensive use of biofuels come from vegetable oils that could derive in a shortage of raw materials necessary for feed purposes, instead, non- edible plant oils can be employed to fulfill this objective [7-10].

Waste frying oil is visualized as one of the non- edible vegetable oils that regarded to be unsuitable for human consumption. During frying process, the oil is repeatedly subjected to high temperatures in the presence of air and moisture. Under these conditions, degradation reaction proceeds, leading to several changes in the physical and chemical properties of the oil [11-13]. If the frying process is continued, further degradation will occur, and finally the oil will not be appropriate for frying and it has to be discarded.

Disposal of waste cooking oils creates serious environmental problems [14]. This concept motivated researchers not only to tackle the disposal matter of the used oil but also to find a way for producing a renewable liquid biofuel from these low- cost wastes [15-20].

*Correspondence to E-mail: eslamalamrousi@yahoo.com

DOI: $10.21608 /$ EJCHEM.2017.2349

(C) 2017 The National Information \& Documentation Center (NIDOC) 
Currently, transesterification is the primary route for producing biofuels (particularly biodiesel) from plant oils [21-24]. Although this process has many benefits, however, it shows several disadvantages $[25,26]^{\circ}$ To eliminate or even to minimize such drawbacks, some modern technologies have been developed, such as hydrotreating and hydrocracking processes [27,32]. These technologies have significant potential as the produced oils have better fuel properties than those obtained via transesterification. In addition, they employ the existing infrastructure of petroleum refineries [33].

This study aimed to apply the hydrocracking technique for producing clean biofuel from anon- edible waste cooking oil, using a novel zeolite catalyst. A derivation of the optimum operating conditions for attainment the highest biofuel yield with the best quality is an essential target of this work.

\section{Experimental \\ Feedstock}

Waste cooking oil (WCO) collected from some restaurants, fast food and households, was employed in this study as a feedstock. The sample was heated to $60{ }^{0} \mathrm{C}$ and filtered under vacuum in press filter to get clear and clean oil, then dehydrated using anhydrous sodium sulfate, left over night and finally filtered again under vacuum.

\section{Catalyst}

HYDEX-L, a novel zeolite based catalyst, developed by the SUD-CHEMIE GROUP, was used here to catalyze the hydrocracking reaction. It has extrusion shape with $1.5,2.5 \mathrm{~mm}$ size, surface area of $=290 \mathrm{~m}^{2} / \mathrm{gm}$ and total pore volume amount to $0.3331 \mathrm{~cm}^{3}$. The catalyst was dried at $120^{\circ} \mathrm{C}$ for $3 \mathrm{hrs}$, calcined at $450^{\circ} \mathrm{C}$ for $6 \mathrm{hrs}$ in air and then reduced at $450^{\circ} \mathrm{C}$ under $1 \mathrm{MPa}$ hydrogen pressure .

\section{Catalytic activity testing}

Hydrocracking of the waste frying oil over zeolite catalyst was examined at various experimental conditions of temperatures, pressures and liquid hourly space velocities, to investigate the influence of each of these factors on the procession of the reaction, and also to find out the optimum operating circumstances for getting the highest yield with the best quality of the desired product .

The experiments were carried out in a high pressure cata - test unit equipped with a fixed bed reactor. A simplified schematic diagram of the employed setup is illustrated in Fig.1. 


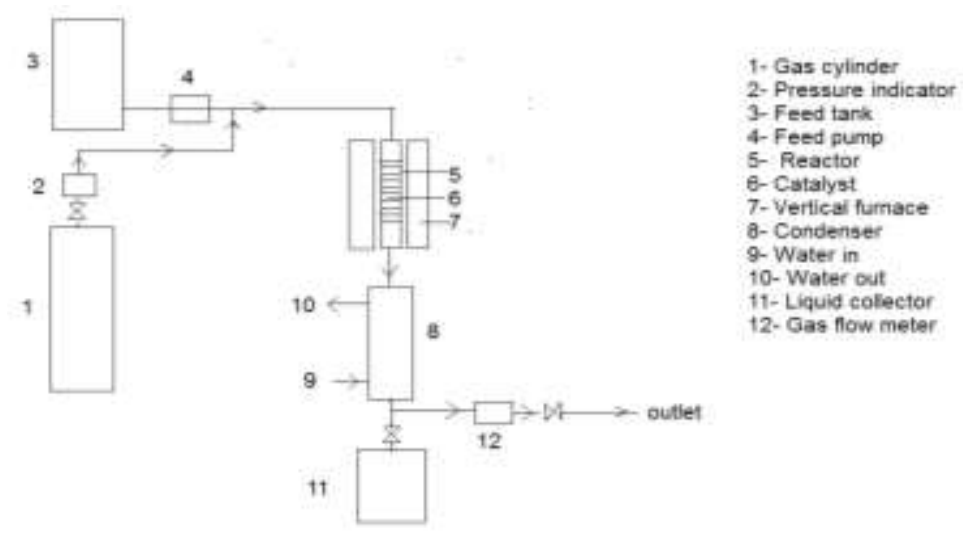

Fig.1. Simplified schematic diagram of cata-Test Unit.

The reactor was loaded with the zeolite catalyst mixed with the same volume of ceramics and placed in a vertical furnace. The unit was flushed with hydrogen gas, and kept constant under $\mathrm{H}_{2}$ pressure to check any leakage, thereafter; the operating conditions were adjusted as required. Once the steady state had reached, the feed was pumped to the top of the reactor by means of a piston pump having an adjusting knob. The reactor effluents were cold in a water condenser, the gases were passed through a gas meter to the outlet, whereas the liquid product was collected in a receiver, estimated, analyzed and evaluated.

The obtained biofuel was fractionated to three cuts with boiling points in the range of IBP- $150^{\circ} \mathrm{C}, 150-250^{\circ} \mathrm{C}$ and $250-<344^{\circ} \mathrm{C}$, which corres ponds to gasoline, kerosene and gas oil- like fractions, respectively. The remainder (that boiled above $344^{\circ} \mathrm{C}$ ) is considered as the unconverted oil or residuals. Both the hydrocracked products and the individual fractions that attained at the optimum operating conditions were characterized according to the different ASTM methods.

\section{Results and Discussion}

Effect of liquid hourly space velocity (LHSV)

The influence of LHSV on hydrocracking the used cooking oil (UCO) over zeolite catalyst was studied at fixed reaction conditions of $450^{\circ} \mathrm{C}, 2.5 \mathrm{MPa}$ hydrogen pressure and $1600 \mathrm{~L} / \mathrm{L} \mathrm{H}_{2} /$ feed ratio. The distribution and properties of the products are declared in Table 1 and Fig. 2.

The data reveal that almost complete conversion of the feed to gases and organic liquid (get to $97.22 \mathrm{wt} \%$ ) has been occurred throughout the investigated range of LHSV. On reducing the velocity of the feed, surplus gases were then evolved, accompanied by an equivalent diminution of the obtained liquid. This resulted from the ascendancy of sever hydrocracking at longer contact time. Accordingly, 13.21, 15.98, 18.81 wt \% gases associated with 86.79, 84.02 and $81.19 \mathrm{wt} \%$ of OLP were obtained at $5,2.5$ and $1 \mathrm{~h}^{-1}$, respectively.

Egypt. J. Chem. 60, No.1 (2017) 
TABLE 1. Distribution of the hydrocracked used cooking oil products obtained at various LHS V.

\begin{tabular}{|c|c|c|c|}
\hline Hydrocracked Products & $1 \mathrm{~h}^{-1}$ & $2.5 \mathrm{~h}^{-1}$ & $5 h^{-1}$ \\
\hline \multicolumn{4}{|l|}{ Hydrocracked products, Wt $\%$} \\
\hline Gases, Wt \% & 18.81 & 15.98 & 13.21 \\
\hline Liquids, Wt \% & 81.19 & 84.02 & 86.79 \\
\hline Water content, Wt \% & - & - & - \\
\hline Oil content, Wt \% & 81.19 & 84.02 & 86.79 \\
\hline Density at $20^{\circ} \mathrm{C}$ & 0.8086 & 0.8301 & 0.8373 \\
\hline Kinematic viscosity, cSt at $40^{\circ} \mathrm{C}$ & 1.214 & 2.841 & 3.202 \\
\hline \multicolumn{4}{|l|}{ ASTM distillation, Vol. $\% /{ }^{\circ} \mathrm{C}$} \\
\hline IBP & 50 & 50 & 50 \\
\hline 10 & 54 & 60 & 61 \\
\hline 20 & 60 & 71 & 72 \\
\hline 30 & 71 & 89 & 83 \\
\hline 40 & 79 & 90 & 100 \\
\hline 50 & 88 & 110 & 123 \\
\hline 60 & 115 & 130 & 140 \\
\hline 70 & 135 & 150 & 165 \\
\hline 80 & 165 & 190 & 203 \\
\hline 90 & 186 & 248 & 264 \\
\hline FBP & 195 & 272 & 281 \\
\hline Recovered, Vol. \% & 93 & 94 & 95 \\
\hline Gasoline , Vol. \% & 75 & 70 & 67 \\
\hline Kerosene, Vol. \% & 18 & 20 & 20 \\
\hline Gas oil, Vol. \% & - & 4 & 8 \\
\hline Residue and losses, Vol. \% & 7 & 6 & 5 \\
\hline Conversion of $>344^{\circ} \mathrm{C}$ fraction, $\mathrm{Wt} \%$ & 97.22 & 97.22 & 97.22 \\
\hline Liquid biofuel yield, Wt $\%$ & 74.165 & 77.912 & 81.58 \\
\hline
\end{tabular}

Temperature: $450{ }^{\circ} \mathrm{C}$, Pressure: $2.5 \mathrm{MPa}$ and $\mathrm{H}_{2} /$ feed: $1600 \mathrm{~L} / \mathrm{L}$.

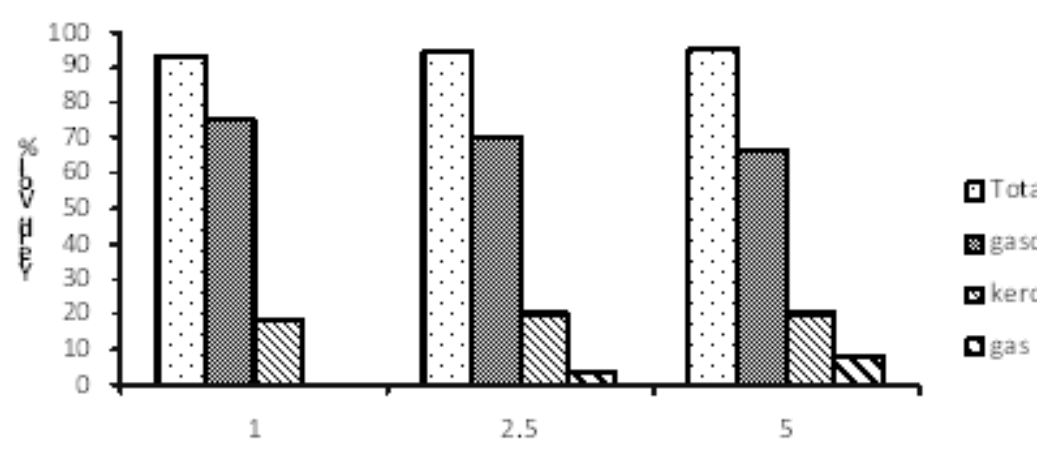

Fig. 2. Distribution of the individual fractions of the biofuel obtained from hydrocracked used cooking oil as a function of LHS V.

Egypt. J. Chem. 60, No.1 (2017) 
The obtained oil is characterized by adequate values of densities and viscosities (that varies between0.8373 to 0.8086) and (from 3.202 to 1.214), respectively, which are completely appropriate for a fuel (taking in consideration that 0.9264 and $42.2 \mathrm{cSt}$ were determined for the feed, consequently).

The ASTM distillation results reflect the abundance of gasoline fraction in the hydrocracked products that represents the principal constituent of the biofuel yields attained at all the examined LHSVs. It fluctuates from 67 up to 75 vol\% of the acquired biofuels. This evidences that, the us ed zeolite catalyst is highly selective to gasoline production that enhanced at longer contact time. Consequently, this concomitant with deficiency of the heavier fractions particularly at lower space velocities, so much that the gas oil fraction is quite vanished at $1 \mathrm{~h}^{-1}$.

The highest deal of liquid biofuel equivalent to $81.58 \mathrm{wt} \%$ can be realized at $5 \mathrm{~h}^{-1}$, hence it was selected as the optimal LHSV to be applied for the next study.

\section{Effect of reaction temperature}

The performance of zeolite catalyst for hydrocraking used cooking oil (UCO), as a function of reaction temperature was examined at constant circumstances (i.e. : LHSV of $5 \mathrm{~h}^{-1}$, pressure $2.5 \mathrm{MPa}$ and $\mathrm{H}_{2}$ /feed ratio $1600 \mathrm{~L} / \mathrm{L}$ ).

The data illustrated in Table 2 indicate the significant influence of $400{ }^{\circ} \mathrm{C}$ and $450{ }^{\circ} \mathrm{C}$ reaction temperature on the conversion, that get to the maximum of 97.22 wt $\%$ at both temperatures. Nevertheless, the worst transformation has been occurred at $350{ }^{\circ} \mathrm{C}$, as it gives only $5.55 \mathrm{wt} \%$ of the converted product. This signifies that such relatively low temperature is not sufficient (to a certain degree) to promote the hydrocracking reaction to proceed.

Upon raising the reaction temperature from $350^{\circ} \mathrm{C}$ up to $450^{\circ} \mathrm{C}$, gradual increases of gaseous product (from 5.54 to $13.21 \mathrm{wt} \%$ ), as sociated with dropping in the liquid yields (from 94.46 to $86.79 w \mathrm{wt} \%$ ) can be observed.

Intensive temperatures have markedly improved both density and viscosity of the oil yield. The organic liquid products (OLPs) exhibit density and viscosity values of 0.8917 and $30,171 \mathrm{cSt}$ at $350^{\circ} \mathrm{C}$ that progressively ameliorated to become 0.8373 and $3.202 \mathrm{cSt}$ at $450^{\circ} \mathrm{C}$, respectively. The high viscosity observed at $350^{\circ} \mathrm{C}$ may be ascribed to the saturation of the double bonds of the oil molecules due to the predomination of the exothermic hydrogenation reaction (that competed with cracking reaction) at such relatively lower temperature.

The disappearance of water all during the applied temperature range substantiates that the reaction implemented neither via decarbonylation nor hydrodeoxygenation pathway ${ }^{(33)}$. The distillation data demonstrate the domination of gasoline fraction in the hydroconverted products particularly at $400^{\circ} \mathrm{C}$ and $450^{\circ} \mathrm{C}$ that constitutes 56 and 67 vol\% of the biofuel attained, whereas kerosene amounts to 26 and $20 \mathrm{vol} \%$, added to 14 and 8 vol\% gas oil were achieved at both temperatures, respectively (Fig. 3). 
TABLE 2. Distribution of the hydrocracked used cooking oil products obtained at various temperatures.

\begin{tabular}{|c|c|c|c|}
\hline Hydrocracked Products & $350{ }^{0} \mathrm{C}$ & $400{ }^{\circ} \mathrm{C}$ & $450^{\circ} \mathrm{C}$ \\
\hline \multicolumn{4}{|l|}{ Hydrocracked products, Wt \% } \\
\hline Gases, Wt \% & 5.54 & 12.14 & 13.21 \\
\hline Liquids , Wt \% & 94.46 & 87.86 & 86.79 \\
\hline Water content, Wt \% & - & - & - \\
\hline Oil content, Wt \% & 94.46 & 87.86 & 86.79 \\
\hline Density at $20^{\circ} \mathrm{C}$ & 0.8917 & 0.8318 & 0.8373 \\
\hline Kinematic viscosity, cSt, at $40^{\circ} \mathrm{C}$ & 30.171 & 4.793 & 3.202 \\
\hline \multicolumn{4}{|l|}{ ASTM distillation, Vol. $\% /{ }^{\circ} \mathrm{C}$} \\
\hline IBP & 95 & 60 & 50 \\
\hline 10 & 115 & 72 & 61 \\
\hline 20 & 148 & 80 & 72 \\
\hline 30 & 180 & 103 & 83 \\
\hline 40 & 261 & 118 & 100 \\
\hline 50 & 272 & 130 & 123 \\
\hline 60 & 295 & 155 & 140 \\
\hline 70 & - & 185 & 165 \\
\hline 80 & - & 249 & 203 \\
\hline 90 & - & 275 & 264 \\
\hline FBP & 305 & 283 & 281 \\
\hline Recovered, Vol. \% & 65 & 96 & 95 \\
\hline Gasoline , Vol. \% & 20 & 56 & 67 \\
\hline Kerosene, Vol. \% & 15 & 26 & 20 \\
\hline Gas oil, Vol. \% & 30 & 14 & 8 \\
\hline Residue and losses , Vol. \% & 35 & 4 & 5 \\
\hline Conversion of $>344{ }^{\circ} \mathrm{C}$ fraction, $\mathrm{Wt} \%$ & 5.55 & 97.22 & 97.22 \\
\hline Liquid biofuel yield, Wt \% & 62.858 & 82.997 & 81.58 \\
\hline
\end{tabular}

Pressure: $2.5 \mathrm{MPa}$, L.H.S.V.: $5 \mathrm{~h}^{-1}$ and $\mathrm{H}_{2} /$ feed: $1600 \mathrm{~L} / \mathrm{L}$

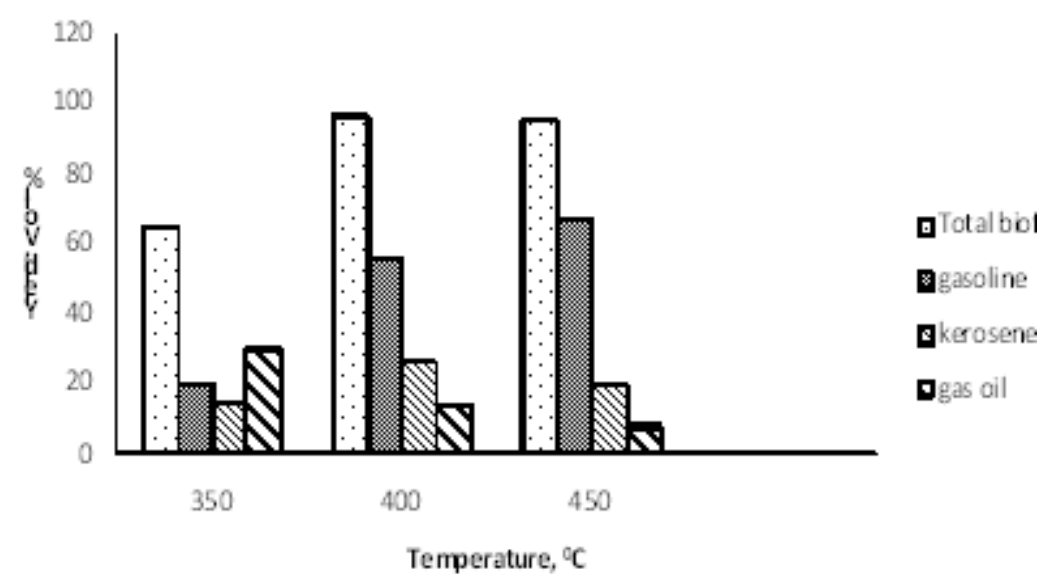

Fig. 3. Distribution of the individual fractions of the biofuel obtained from hydrocraked used cooking oil as a function of Temperature.

Egypt. J. Chem. 60, No.1 (2017) 
The biofuel accomplished at $350^{\circ} \mathrm{C}$ is characterized by the relative abundance of the heavier gas oil fraction, but the total biofuel liquid yield is not satisfactory as it represents only $62.858 \mathrm{wt} \%$.

Accordingly, the most gratifying temperature that regarded as the best for further investigation is $400^{\circ} \mathrm{C}$, since it shows a high conversion and high biofuel yield comprised about $83 \mathrm{wt} \%$, also it reveals proper values for density and viscosity.

\section{Effect of hydrogen pressure}

The data in Table 3 shed light upon the distribution of the hydrocracked products of used cooking oil (WCO), using zeolite catalyst. The experiments were carried out at a different $\mathrm{H}_{2}$ hydrogen pressure in the range of 1 to $5 \mathrm{MPa}$, and at constant reaction conditions (i.e. $400^{\circ} \mathrm{C}, 5 \mathrm{~h}^{-1} \mathrm{LHSV}$ and $1600 \mathrm{~L} / \mathrm{L}, \mathrm{H}_{2} /$ feed ratio).

TABLE 3. Distribution of the hydrocracked used cooking oil products obtained at various $\mathrm{H}_{2}$ pressure.

\begin{tabular}{|c|c|c|c|}
\hline Hydrocracked Products & 1.0 MPa & $2.5 \mathrm{MPa}$ & 5.0Mpa \\
\hline \multicolumn{4}{|l|}{ Hydrocracked products, Wt \% } \\
\hline Gases, Wt \% & 2.20 & 12.14 & 18.98 \\
\hline Liquids, Wt \% & 97.80 & 87.86 & 81.02 \\
\hline Water content, Wt \% & - & - & - \\
\hline Oil content, Wt \% & 97.80 & 87.86 & 81.02 \\
\hline Density at $20^{\circ} \mathrm{C}$ & 0.8895 & 0.8318 & 0.8385 \\
\hline Kinematic viscosity, cSt, at $40^{\circ} \mathrm{C}$ & 15.672 & 4.793 & 3.653 \\
\hline \multicolumn{4}{|l|}{ ASTM distillation, Vol. $\% /{ }^{\circ} \mathrm{C}$} \\
\hline IBP & 80 & 60 & 50 \\
\hline 10 & 89 & 72 & 68 \\
\hline 20 & 100 & 80 & 78 \\
\hline 30 & 138 & 103 & 90 \\
\hline 40 & 168 & 118 & 110 \\
\hline 50 & 259 & 130 & 123 \\
\hline 60 & 281 & 155 & 145 \\
\hline 70 & - & 185 & 165 \\
\hline 80 & - & 249 & 202 \\
\hline 90 & - & 275 & 260 \\
\hline FBP & 295 & 283 & 279 \\
\hline Recovered, Vol. \% & 69 & 96 & 95 \\
\hline Gasoline, Vol. \% & 30 & 56 & 65 \\
\hline Kerosene, Vol. \% & 19 & 26 & 20 \\
\hline Gas oil, Vol. \% & 20 & 14 & 10 \\
\hline Residue and losses , Vol. \% & 31 & 4 & 5 \\
\hline Conversion of $>344^{\circ} \mathrm{C}$ fraction, $\mathrm{Wt} \%$ & 16.667 & 97.22 & 97.22 \\
\hline Liquid biofuel yield, Wt $\%$ & 69.886 & 82.997 & 73.939 \\
\hline
\end{tabular}

Temperature: $400^{\circ} \mathrm{C}$, LHSV. : $5 \mathrm{~h}^{-1}$ and $\mathrm{H}_{2} /$ feed: $1600 \mathrm{~L} / \mathrm{L}$. 
97.22 wt \% conversion of the heavy fraction in the feedstock with a boiling point higher than $344^{\circ} \mathrm{C}$ was accomplished at pressures beyond $1 \mathrm{MPa}$. Inhibition of the conversion is clearly obvious at the lowest pressure of $1 \mathrm{MPa}$, at which the pressure is not sufficient to enhance the hydrocracking reaction, considering only $16.67 \mathrm{wt} \%$ of the feed with a boiling point above $344^{\circ} \mathrm{C}$, was hydrocracked. The produced liquid is then characterized by high density and viscosity values, comprised 0.8895 and $15.672 \mathrm{cSt}$ respectively.

The data also reflect the significant influence of the hydrogen pressure on the amounts of the emanated gases. A substantialquantity of the undesirable gases in as much as $18.98 \mathrm{wt} \%$ was released at the highest pressure of $5 \mathrm{MPa}$, which led to consequential abatement in the magnitude of the produced liquid biofuel (comprised $73.939 \mathrm{wt} \%$ ). On the other hand, at the lowest pressure of $1 \mathrm{MPa}$, only $2.2 \mathrm{wt} \%$ of gases was obtained. However, the results of this run are not satisfactory, as it gives the worst yield of liquid biofuel (amount to $69.886 \mathrm{wt} \%$ ). Therefore, neither the experiment performed at $5 \mathrm{MPa}$ nor that carried out at 1 $\mathrm{MPa}$ are accepted to realize our target.

It is apparent from the table, the mild amount of gases (i.e. $12.14 \mathrm{wt} \%$ ) and the good yield of OLP which has a perfect density and viscosity values of o.8318 and $4.793 \mathrm{cSt}$ respectively, can be acquired at $2.5 \mathrm{MPa}$. At this pressure, the highest yield of petroleum- like fraction, as far as $\approx 83 \mathrm{wt} \%$ was accomplished, and composed mainly from $56 \mathrm{vol} \%$ gasoline as well as $26 \mathrm{vol} \%$ kerosene and 14 vol\% gas oil (Fig. 4). So, $2.5 \mathrm{MPa}$ has been recommended to be the optimal hydrogen pressure value.

Finally, it could be concluded that, the best operating variables for hydrocracking the waste cooking oil on zeolite catalyst are $5 \mathrm{~h}^{-1} \mathrm{LHSV}, 400^{\circ} \mathrm{C}$ and 2.5 MPa hydrogen pressure.

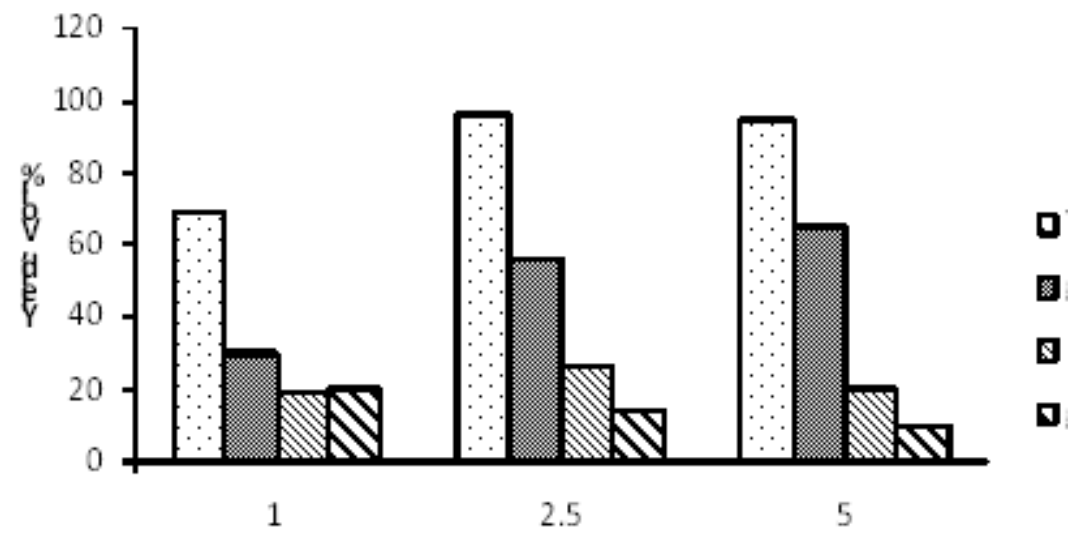

Fig. 4. Distribution of the individual fractions of the biofuel obtained from hydrocracked used cooking oil as a function of pressure.

Egypt. J. Chem. 60, No.1 (2017) 
Evaluation of the prepared petroleum- like fractions

The physicochemical properties of gasoline, kerosene and gas oil - like distillates obtained from fractionating the biofuel, produced from the WCO and hydrocracked over zeolite catalyst at the derived optimum operating conditions, were determined and compared with those of the corresponding commercial petroleum fractions. Their results are declared in Table 4.

The demonstrated data evidenced that, the characteristics of gasoline- like distillate is almost congruent with the properties of petroleum gasoline, with negligible differences. The calorific value of the prepared gasoline is to somewhat lower than that originated from the mineral oil, as it possesses a value of $46889 \mathrm{j} / \mathrm{kg}$ compared to $49360 \mathrm{j} / \mathrm{kg}$ respectively. This drop in the calorific value is possibly arisen from remaining some of the oxygenated compounds which existed in the molecular structure of the parent oil, whereas petroleum gasoline is constituted principally from saturated hydrocarbons.

TABLE 4. Physicochemical characteristics of petroleum like fractions compared with their corresponding petroleum refinery distillates .

\begin{tabular}{|l|c|c|c|c|c|c|}
\hline Properties & $\begin{array}{c}\text { Petroleum } \\
\text { gasoline }\end{array}$ & $\begin{array}{c}\text { Gasoline } \\
\text { like fraction }\end{array}$ & $\begin{array}{c}\text { Petroleum } \\
\text { kerosene }\end{array}$ & $\begin{array}{c}\text { Kerosene } \\
\text { like } \\
\text { fraction }\end{array}$ & $\begin{array}{c}\text { Petroleum } \\
\text { gas oil }\end{array}$ & $\begin{array}{c}\text { Gas oil } \\
\text { like } \\
\text { fraction }\end{array}$ \\
\hline Yield, wt\% & - & 41.938 & - & 22.061 & - & 12.176 \\
\hline Density /20 ${ }^{0} \mathrm{C}$ & 0.748 & 0.7489 & 0.840 & 0.8485 & 0.8543 & 0.8697 \\
\hline $\begin{array}{l}\text { Kinematic viscosity } \\
\text { /40 cSt. }\end{array}$ & 0.5 & 0.55 & 1.5 & 1.74 & 6 & 6.25 \\
\hline Ash content , wt\% & 0.1 & Nil & Nil & Nil & Nil & Nil \\
\hline Molecular weight & 105 & 105 & 170 & 178 & 230 & 254 \\
\hline Calorific value, j/kg & 49360 & 46889 & 47220 & 45152 & 44300 & 43999 \\
\hline Sulfur content, $\mathrm{wt} \%$ & 0.05 & Nil & 0.3 & Nil & 0.3 & Nil \\
\hline Pour point , ${ }^{0} \mathrm{C}$ & -40 & -36 & -40 & -36 & Zero & 3 \\
\hline Refractive index & 1.4100 & 1.41173 & 1.4458 & 1.4494 & 1.4620 & 1.4698 \\
\hline Smoke point , $\mathrm{mm}$ & - & - & 26 & 25 & - & - \\
\hline Flash point , ${ }^{\circ} \mathrm{C}$ & - & - & 58 & 60 & 150 & 125 \\
\hline Cetane number & - & - & - & - & 47 & 45.41 \\
\hline Carbon residue, wt\% & Nil & Nil & 1.5 & Nil & 0.3 & Nil \\
\hline
\end{tabular}

The other specifications of the biogasoline, derived from the WCO, such as specific gravity, kinematic viscosity molecular weight, pour point, carbon residue, and ash content are completely compatible with those of mineral gasoline. Furthermore, the obtained biogasoline is distinguished from that ensued from petroleum by the lack of sulfur, which presents a good advantage in reducing the harmful emissions of the exhaust gases and also inhibiting corrosion in engines . 
In the same manner, the properties of the $2^{\text {nd }}$ fraction that boiled in kerosene range were also specified, and compared with those of the commercial kerosene. Data in Table 4 indicate that, the properties of the biokerosene sample is approximately very close to that generated from petroleum source, with the exception of calorific value, which shows, to some extent ,a lower magnitude, amounting to $45152 \mathrm{j} / \mathrm{kg}$ compared to $47220 \mathrm{j} / \mathrm{kg}$ for that derived from mineral oil . As mentioned previously, this decrement can be referred also to the oxygenated compounds involved in the produced bio-kerosene, originated from the oxygenated feature of its virgin oil.

As noticed from the data, all the other specifications of the obtained biokerosene are highly concordant with the corresponding fraction of petroleum crude oil. Moreover, it is ashless and not contains the undesirable sulfur compounds which cause the hazardous emissions and pollutes the environment.

Table 4 exposes also the properties of the gas oil fractions, which reflects the adequate resemblance of the physicochemical characteristics of both bio- and mineral fuels. Each of the calorific value, ash content viscosity, density, pour point, cetane number, flash point and carbon residue of the bio-gas oil is completely compatible with that of the corresponding fractions issued from petroleum oil. In addition, the gas oil -like distillate is distinguished by the lack of sulfur compounds.

Finally, the obtained data lead us to conclude that, the various distillates (i.e. gasoline, kerosene and gas oil - like fractions) generated from hydrocracking the WCO, can be definitely employed as alternates to fossil fuels, as they possess almost similar properties.

\section{Conclusions}

High yield with good properties of clean biofuel was obtained from hydrocracking WCO on zeolite catalyst .

$83 \mathrm{wt} \%$ of biofuel yield was accomplished at the optimum operating conditions of $400{ }^{0} \mathrm{C}, 5 \mathrm{~h}^{-1}$ and $2.5 \mathrm{MPa}$ hydrogen pressure, which incorporates 56 vol\% gasoline, $26 \%$ kerosene and $14 \%$ gas oil-like fractions.

The physicochemical characteristics of the acquired fractions are completely compatible with those of the corresponding petroleum distillates.

The attained biofuels possess more advantages as they are ashless, contain no sulfure or aromatic compounds, so, they can be utilized deservedly as alternates to fossil fuels. 


\section{References}

1. Patil, P.D., Gude, V.G. and Deny, S., Biodiesel production from jatropha curcas, waste cooking and camelina siva oils. Ind. Eng. Chem. Res. 48 (24) 10850 (2009).

2. El Khatib, S.A., Hanafi, S.A., Arief, M.M.H and Al- Amrousi E.F., Optimizing the biofuel production by hydrotreating jojoba oil International Journal of Academic Research , Baku, Azerbaijan, 6 (3), 194 (2104).

3. Kumar, P., Barrett, D.M., Delwich, M.J. and S troeve, P., Methods for pretreatment of lignocellulosic biomass for efficient hydrolysis and biofuel production. Ind. Eng. Chem. Res., 48, 3713 (2009).

4. Vicent, G., Martinez, M. and Aracil, J., A comparative study of vegetable oils in biodiesel production in spain. Energy and fuels, 20, 394 (2006).

5. Mahamuni, N.N. and Adewuyi, Y.G., Optimization of synthesis of Biodiesel via ultrasound-enhanced base- catalyzed transesterification of soybean oil using a multifrequency ultrasonic reactor . Energy \& fuels, 23, 2757 (2009).

6. Knothe, G., Cermak, S.C. and Evangelista, R.I., Cuphea oil as Source of biodiesel with improved fuel properties caused by high content of methyl decanoate., Energy \& Fuels, 23, 1743 (2009).

7. Sarin, R., Sharma, M., Sinharay, S. and Malhorta, P.K., Jatropha- palm biodiesel belends. An optimum mix for Asia. Fuel, 86, 1365(2007).

8. Einloft, J., Magalhaes, T.O., Donato, A., Dullius, J. and Ligabue, R., Biodiesel from rice brane oil transesterification by tin compounds, Energy \& fuels, 22, 671(2008).

9. Radwan, M.S., Ismail, M. A., Elfeky, S.M.S. and Abou Elyazeed, O.S.M., Jojoba methyl ester as a diesel fuel substitute, preparation and characterization., Appl. Thermal. Energy, 27, 314 (2007).

10. Mikulec, J., Cvengros, J., Jorikova, L., Banic, M. and Kleinova. A., Production of diesel fuels from waste triacylglycerol by hydrodeoxy genation . $44^{\text {th }}$ International Petroleum Conference, Bratislava, Slovak republic September 21-22 (2009).

11. Aladedunye, F.A. and Przybylski, R., Protecting oil during frying : A comparative study, Eur. J Lipid Sci. Tech., 111, 893(2009).

12. Knothe, G. and Steidly, K.P., A comparison of used cooking oils: Avery heterogeneous feed stock for biodiesel., Bioresource Techno., 100 (23), 5796 (2009).

13. Sanli, H., Canakci, M. and Alptekin, E, Characterization of waste frying oils obtained from different facilities., World Renewable Energy Congress Sweden , 8-13 May, Linkoping, Sweden (2011) . 
14. Agriculture and Food Development Authority, waste oils and fats as biodiesel feedstocks : an assessment of their potential in the EU, AlTENER program NTB-NETT phase IV, Task 4 , Final Report, March (2000).

15. Predojevic, Z., The production of biodiesel from waste frying oils .A comparison of different purification steps, Fuel, 17, 3522 (2008).

16. Canakci, M., The potential of restaurants waste lipids as biofuel feedstock's, Bioresource Techno., 98, 183(2007).

17. Pinzi, S., Garcia, I.L., Lopez- Gimenez, E.J., Luque De Castro, M.D., Dorado, G. and Dorado, M.P., The ideal vegetable oil - based biodiesel composition : A review \& Social economical and technical implications., Energy \&Fuels, 23(5), 2325 (2009).

18. Zhang , Y., Dube, M. A., Mclean, D.D. and Kates, M., Biodiesel production from waste cooking oil . 2 Economic assessment and sensitivity analysis., Bioresour. Tehnol., 90, 229 (2003).

19. Refaat, A.A., Attia, N.K., Sibak, H.A., El Sheltawy, S.T. and El Diwani, G.I., Production, optimization and quality assessment of biodiesel from waste vegetable oil., Ind. J. Environ. Sci. Technol., 5, 75(2006).

20. Phan, A.N. and Phan, T.M., Biodiesel production from waste cooking oils., Fuel, 87, 3490 (2008).

21. Wang, Y., Pengzhan Liu, S.O. and Zhang, Z., Preparation of biodiesel from waste cooking oil via two - step catalyzed process., Energy Converse. Manage., 48, 184 (2007).

22. Cao, F., Chen, Y., Zhai, F., Li., J, Wang, J., Wang, X., Wang, S. and Zhu, W., Biodiesel production from high acid value waste frying oil cataly zed by superacid and heteropoly acid . Biotechnol, Bioeng., 101, 93(2008).

23. Ja Cobson, K., Gopinath, R., Meher, L.C. and Dalaii, A.K., Solid acid catalyzed biodiesel production from waste cooking oil., Appl. Catal. B. Environ, 85, 86 (2008).

24. Lou, W.Y., Zong, M.H. and Duan, Z.Q., Efficient production of biodiesel from high free fatty acid- containing waste oils using various carbohydrate - derived solid acid catalysts. Bioresourse Technol, 99, 8752 (2008).

25. Hancsok, J., Krar. M., Magyar, S., Boda, L., Hollo, A. and Kallo, D., Investigation of the production of high cetane number bio gas oil from pre-hydrogenated vegetable oils over Pt/HZSM-22/AL $\mathrm{O}_{3}$., Microporous and Mesoporous Materials, 101, 148(2007).

26. Hancsok, J., Kovacs, F. and Krar, M., In Fifth Inter. Symposium on Materials Mode From Renewable Resources, Erfurt, Germany(2005).

27. Simacek, P., Kubicka, K., Sebor, G. and Pospisil, M., Hy droprocessed rapeseed oil as a source of hydrocarbon - based biodiesel., Fuel, 88(3), 456 (2009).

Egypt. J. Chem. 60, No.1 (2017) 
28. Kubicka, D., Simacek, P. and Zilkova, N., Transformation of vegetable oils into hydrocarbons over mesoporous - Alumina- Supported CoMo catalysts., Topics in Catalysis, 53 (1-2), 161(2009).

29. Siregar, T.B. and Amin, N.A.S., Cataly tlic cracking of used palm oil to gasoline over pretreated Cu- ZSM5. J.Techn., 44(F), 69 (2006).

30. Bezergianni, S., Voutetakis , S. and Kalogianni, A., Cataly tic hydrocracking of fresh and used Cooking oil., Ind. Eng. Chem. Res., 48, 8402(2009).

31. El Khatib S. A., Hanafi S. A., Arief M.M. H. and Al-Amrousi E. F. A., Hydrocracking of jojoba oil for green fuel production. Journal of Petroleum Science and Technology, 5 (2), 59-69(2015).

32. Al-Amrousi., E.F.A., Production of petroleum - Like Fractions from Non-edible Oils, Ph.D, Faculty of Science, Benha University (2015).

33. Huber, G.W., Connor, P.O. and Corma, A., Processing biomass in conventional oil refineries. Production of high quality diesel by hydrotreating vegetable oils in heavy vacuum oil mixtures., Appl. Catal. A: General, 329, 120(2007).

(Received 29/8/2016 :

Accepted 17/10/2016) 
إنتاج وقود مماثل للمقطر ات البتروليه من بقايا زيت الطعام

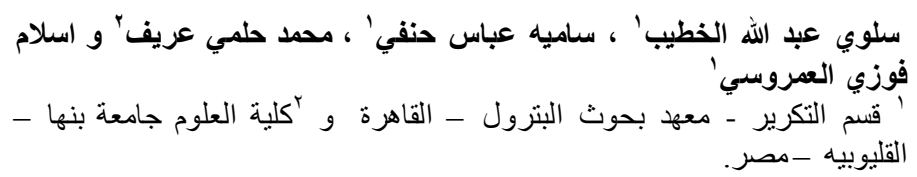

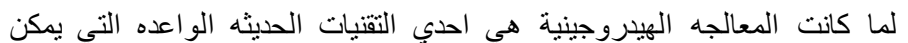

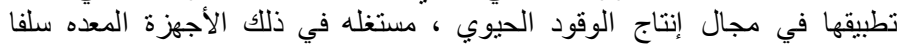

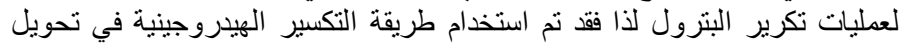

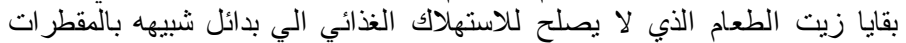

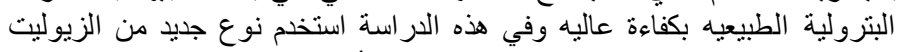

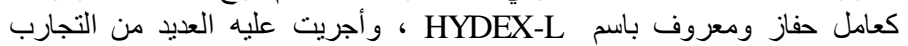

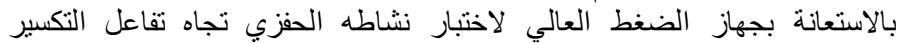

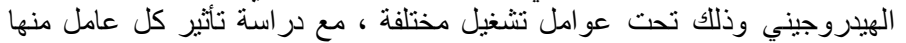

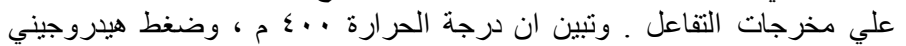

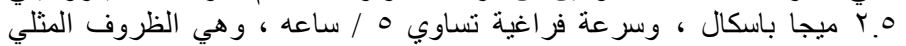

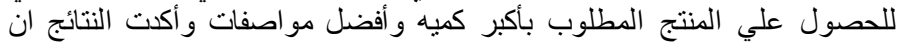

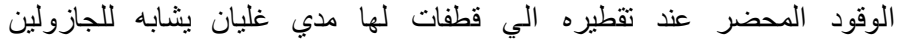

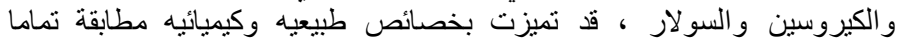

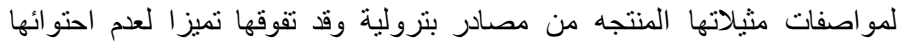

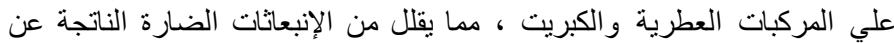

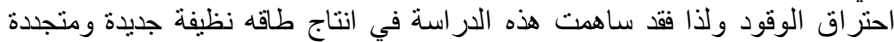

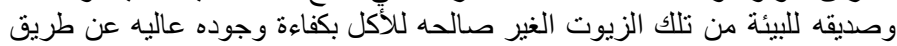

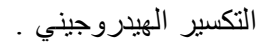

